\title{
Design Projects - The CDIO Context and Experience with Industry
}

\author{
Chris K Mechefske, Brian W Surgenor, John Pelow and Urs P Wyss \\ Department of Mechanical and Materials Engineering \\ Queen's University, Kingston, Ontario, K7L 3N6 \\ chrism@me.queensu.ca
}

\begin{abstract}
As with most engineering schools, the Department of Mechanical and Materials Engineering at Queen's University in Kingston, has a final year capstone design course. Since 1998, capstone projects have involved teams of students working on industry-based problems. This paper summarizes the experience of current and past course coordinators with the university-industry component, comments on how the Conceiv Design Implement Operate (CDIO) elements of the design cycle are handled, and discusses the implications of the two term structure of the course. The first term course MECH 460 Team Project Conceive and Design is mandatory for all students. The second term course MECH 462 Team Project Implement and Operate is optional.
\end{abstract}

\section{Introduction}

The final year capstone design course in the Department of Mechanical and Materials Engineering at Queen's University in Kingston (MECH 460 Team Project - Conceive and Design) aims to prepare students for the transition to the workforce by allowing them to experience 'real' engineering work. Students are expected to apply the skills and knowledge learned in earlier courses to an engineering design problem sponsored by industry. There are three main requirements: 1) to complete a significant engineering design project that addresses the conceive and design elements of the design cycle; 2) to perform the engineering work in a professional manner within the constraints of realistic schedules and budgets; and 3) to work effectively as part of an engineering design team. The elective course, MECH 462 Team Project - Implement and Operate enables team projects that started in MECH 460 to continue on to the implement and operate stages of the design cycle. A key deliverable in MECH 462 is a working prototype, physical mock-up or virtual model of the design.
MECH 460 Team Project - Conceive and Design is a fall term (September-December) course and is mandatory for all students. MECH 462 Team Project - Implement and Operate is a winter term (JanuaryApril) course and is optional. Only about a third of the class (40 to 50 students) elects to continue with MECH 462.

\section{Course Organization}

The list of available projects (and their industrial sponsors) is set by the Department before the beginning of the fall term. All projects are posted on the course website before the first day of classes. Students are encouraged to review this list leading up to the start of the fall term and to contact the Course Coordinator if they have any questions. The course website contains all relevant information and is meant to be self explanatory.

In order to initiate a proposal, a one or two paragraph description must be sent to the Course Coordinator well before the start of the fall term. This proposal usually originates from the industrial partner, but students can propose projects of their own, usually based upon their summer work experience. The proposal is reviewed by the Course Coordinator to ensure that the requirements and expectations of the industrial supervisor match the academic requirements of the course. Students are required to work in teams of four, with only one team assigned per project. Students have the option to select their own team members.

Before the end of the first week of classes, students are asked to form their teams, review the list of available projects and submit a Letter of Intent. The letter must identify, in preferential order, the top three projects of interest to the team. The students are informed that the Letter of Intent should attempt to justify the projects selected. This can be done by 
highlighting the skills and interests of the team members as well as related work/course experience. The Course Coordinator then reviews the letters, and assigns the projects. Teams are assigned to projects by the beginning of the second week of classes.

Each project is assigned a faculty member as an Academic Supervisor The faculty member is responsible for marking the design proposal and final report, and is expected to meet weekly with the team in order to monitor progress and provide advice. The Industry Advisor acts as the client and as such the team may also choose to meet with their advisor at a frequency that is appropriate to the project.

\section{Assessment}

Table 1 shows the assessment breakdown for MECH 460. The oral presentations (design proposal and oral poster presentation) are marked by several academics and industry representatives in attendance. The grade in each case is an average of the marks assigned by all the markers in attendance. All the written material is assessed by the Course Coordinator or the Faculty Supervisor. The final design report carries the largest proportion for the course and has two markers: the supervisor and another faculty member as a second reader.

\section{Table 1: Assessment for MECH 460 Design Project - Conceive and Design.}

\begin{tabular}{|l|c|}
\hline \multicolumn{1}{|c|}{ Item } & Mark \\
\hline Letter of Intent & 0 \\
\hline Design Notebook & 5 \\
\hline Weekly Progress Memo & 10 \\
\hline Oral Presentations (progress and poster) & 10 \\
\hline Design Proposal Report & 10 \\
\hline The Poster & 10 \\
\hline Final Design Report & 50 \\
\hline Industry client assessment & 5 \\
\hline Thank you letter to industry client & 0 \\
\hline Total & 100 \\
\hline
\end{tabular}

Weekly Progress memos are submitted electronically on the Friday of each week, with the exception of the first week (when the Letter of Intent is due) and the last week (when the Poster presentations are held). Students are responsible for providing copies of the memos to their Faculty Supervisor and Industry Advisor, as appropriate.

Each student must have a Design Notebook that provides a record of their individual notes and calculations, as well as a summary of key points and decisions made during each and every group meeting. This book must be permanently bound. All pages must be dated as notes and calculations should be entered.

\section{Financial Support}

Materials and Manufacturing Ontario (MMO) is an Ontario Centre of Excellence committed to making connections between the best university research and the needs of Ontario industry. MMO supports university research in materials and manufacturing, develops partnerships, trains qualified graduate students with an industrial orientation, and supports the transfer of knowledge and technology to industry.

The MMO Connections Program provides an opportunity for undergraduates in their final year in a faculty of engineering or science (possibly in collaboration with students from the business school or other faculties) to undertake a research or problem solving project defined by industry and of specific relevance to the industrial participant's needs. The project should broaden the skill set of the students and help them understand; industrial objectives, the constraints under which industry operates, and how to conduct research and development in an industrial setting.

The support provided by MMO is outlined in Table 2. A base budget for course coordination and administration is provided as well as a specific amount for each project. Team projects are provided with more funding assuming that these projects will be broader in scope. All except a very few $\mathrm{MECH}$ 460 and MECH 462 projects in the Department of Mechanical and Materials Engineering at Queen's are group projects with four students. All the amounts listed are approximations and the final budget allocated to each project is very much project specific. The proposal that each team submits near the beginning of the term includes a proposed budget (with justification) for the proposed work. Relatively small budgets are typical in the MECH 460 to cover such things as travel to the industrial partners site, long distance phone calls, printing and copying. The budgets for MEHC 462 are typically larger given that they include prototyping costs such as materials and shop time.

Financial support from the sponsoring company is usually only provided to build an otherwise too costly prototype or if the prototype will be permanently located at the company's site. 
Table 2: MMO budget guidelines

\begin{tabular}{|l|c|}
\hline \multicolumn{1}{|c|}{ Item } & Budget \\
\hline $\begin{array}{l}\text { Adjunct faculty } \\
\text { (course coordination) }\end{array}$ & $\$ 15,000$ \\
\hline Administrative staff & $\$ 5,000$ \\
\hline One person project & $\$ 500 /$ project \\
\hline Two person project & $\$ 1200 /$ project \\
\hline Three person project & $\$ 3500 /$ project \\
\hline Average project expense & $\$ 1500 /$ project \\
\hline
\end{tabular}

\section{Sample Projects}

Table 3 shows a list of the most recent projects and sponsoring companies.

Table 3: Companies and Projects in Fall 2004.

\begin{tabular}{|c|c|}
\hline Company & Project \\
\hline ASK Science & Autonomous Fish \\
\hline Bosal Canada & $\begin{array}{l}\text { Manufacture of Muffler } \\
\text { Boxes }\end{array}$ \\
\hline $\begin{array}{l}\text { Continental } \\
\text { Conveyor }\end{array}$ & Seal Cartridge Assembly \\
\hline Decoma Autosystems & $\begin{array}{l}\text { Xenon Automotive } \\
\text { Headlamp }\end{array}$ \\
\hline Energy Depot & Integrated Solar Energy \\
\hline Enerworks & $\begin{array}{l}\text { Photovoltaic Powered } \\
\text { Pump }\end{array}$ \\
\hline $\begin{array}{l}\text { Fuel Cell Research } \\
\text { Centre }\end{array}$ & $\begin{array}{l}\text { Fuel Cell Powered Golf } \\
\text { Cart }\end{array}$ \\
\hline Goodyear & Rubber Material Handling \\
\hline Hydrogenics & $\begin{array}{l}\text { Polymer Electrolyte Fuel } \\
\text { Cells }\end{array}$ \\
\hline Kilmarnock & $\begin{array}{l}\text { Machine Noise } \\
\text { Suppression }\end{array}$ \\
\hline Knorr Brake & MCL Actuator Brake Seals \\
\hline KTH Shelburne & $\begin{array}{l}\text { Inspection of Stamping } \\
\text { Operations }\end{array}$ \\
\hline $\begin{array}{l}\text { MCW Custom } \\
\text { Energy }\end{array}$ & $\begin{array}{l}\text { Variable Air Volume } \\
\text { Systems }\end{array}$ \\
\hline Millenium Biologix & Tube Roller \\
\hline Muskoka Renewables & Automated Solar Tracker \\
\hline $\begin{array}{l}\text { Niagara Prosthetics } \\
\# 1\end{array}$ & The Niagara Foot \\
\hline $\begin{array}{l}\text { Niagara Prosthetics } \\
\# 2\end{array}$ & The Prosthetic Pylon \\
\hline
\end{tabular}

\begin{tabular}{|l|l|}
\hline Northern Cables & Ventilation Assessment \\
\hline Pennsafe & Safety Snap Hook Design \\
\hline Procter \& Gamble \#1 & Olay Material Handling \\
\hline Procter \& Gamble \#2 & $\begin{array}{l}\text { Reject Verification } \\
\text { Optimization }\end{array}$ \\
\hline $\begin{array}{l}\text { Pump House } \\
\text { Museum }\end{array}$ & Steam Turbine Demo Unit \\
\hline Samui Corp & Bicycle Trailer Design \\
\hline $\begin{array}{l}\text { Shorewood } \\
\text { Packaging }\end{array}$ & Auxiliary Driven Oscillator \\
\hline Superior Wind & Self-Erecting Wind Tower \\
\hline $\begin{array}{l}\text { Transformix } \\
\text { Engineering }\end{array}$ & Underwater Camera \\
\hline Van Rob Stampings & $\begin{array}{l}\text { Wire-feed Speed in Arc } \\
\text { Welding }\end{array}$ \\
\hline Waterstick Paddles & $\begin{array}{l}\text { Performance Canoe } \\
\text { Paddles }\end{array}$ \\
\hline
\end{tabular}

The sponsoring companies represent a range of manufacturing industries as based on economic sector and size of the company. Some companies sponsor more than one project, although the norm is one project per company.

Figure 1 illustrates a MECH 460/462 project where the subject was the redesign of safety hook. Pensafe (Welland) as a manufacturer of safety hooks submitted a request for the design of a new safety snap hook that could be marketed as a premium hook with improved user ergonomics. In MECH 460, the students designed a hook that operated in an innovative manner, theoretically passed all required safety standards and exhibited weight and cost reduction potentials. In $\mathrm{MECH} 462$, a series of plastic physical prototypes were constructed using a Stratasys Rapid Prototyping Machine (RPM). Changes were made to the design to further reduce material and weight of the snap hook body and improve the operation of the gate keeper and lock lever. Several design iterations were carried out and a number of machined steel prototypes were constructed. The result was an innovative safety snap hook design that passed all legislated safety standards, reduced hook body mass by over $15 \%$ and showed significant ergonomic improvements over existing designs. The MECH 462 Gantt chart for this project is given as Figure 2. It is included as an all too rare example where the actual project timelines kept pace with the timelines set forth by the original Gantt chart. 


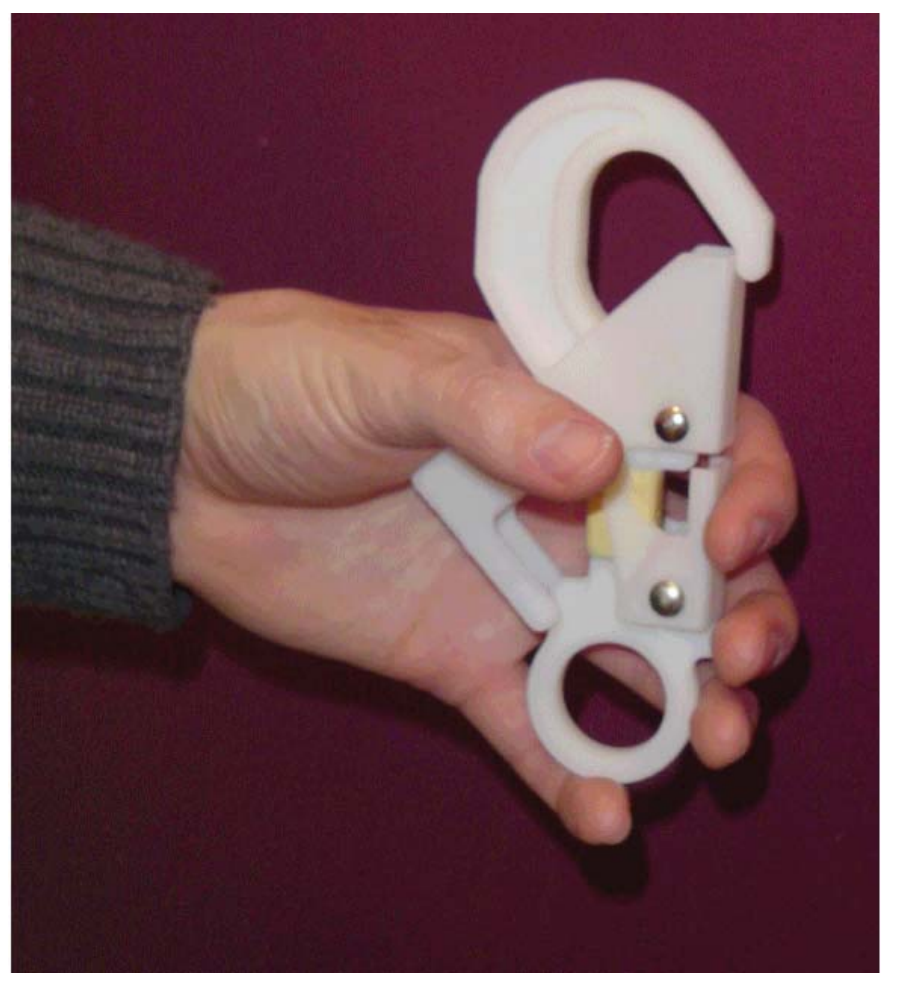

Figure 1: Prototype safety hook from Pensafe project, produced by an RPM

MECH 462 PROJECT SCHEDULE

Schedule as of Jan 27, 2005

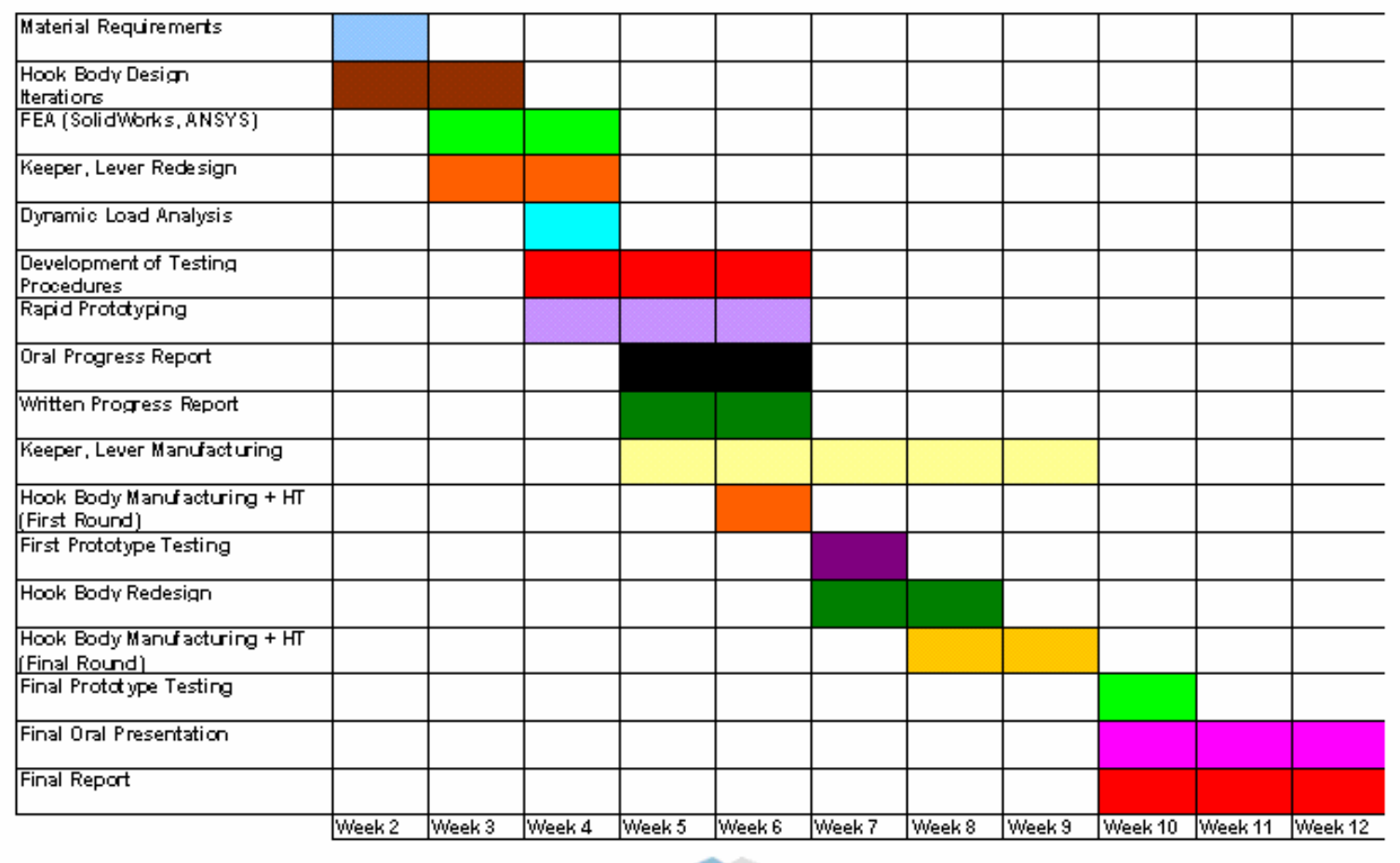

Figure 2: Gantt chart from Pensafe safety hook project 

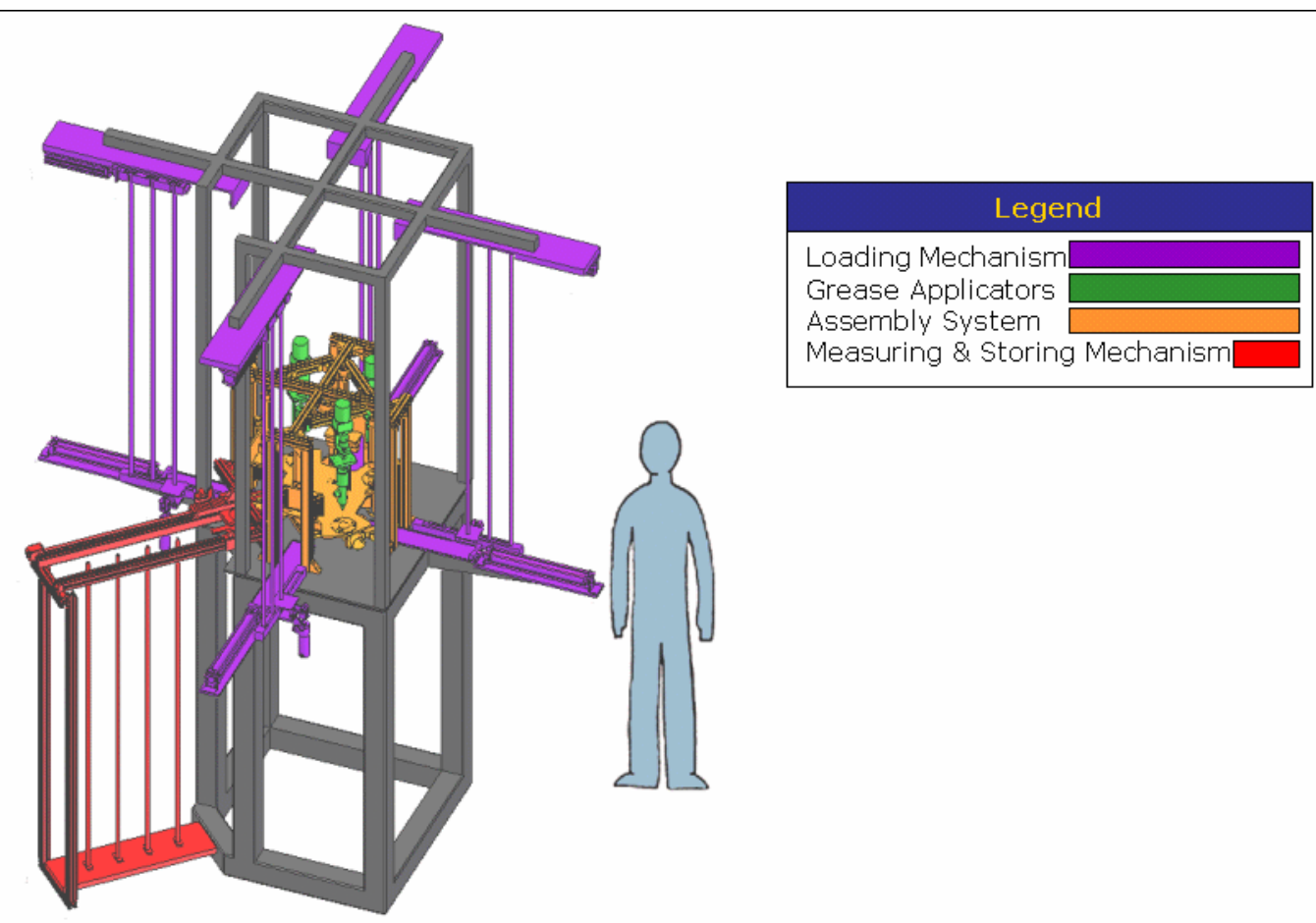

Figure 3: Final design for cartridge assembly machine from Continental Conveyor project

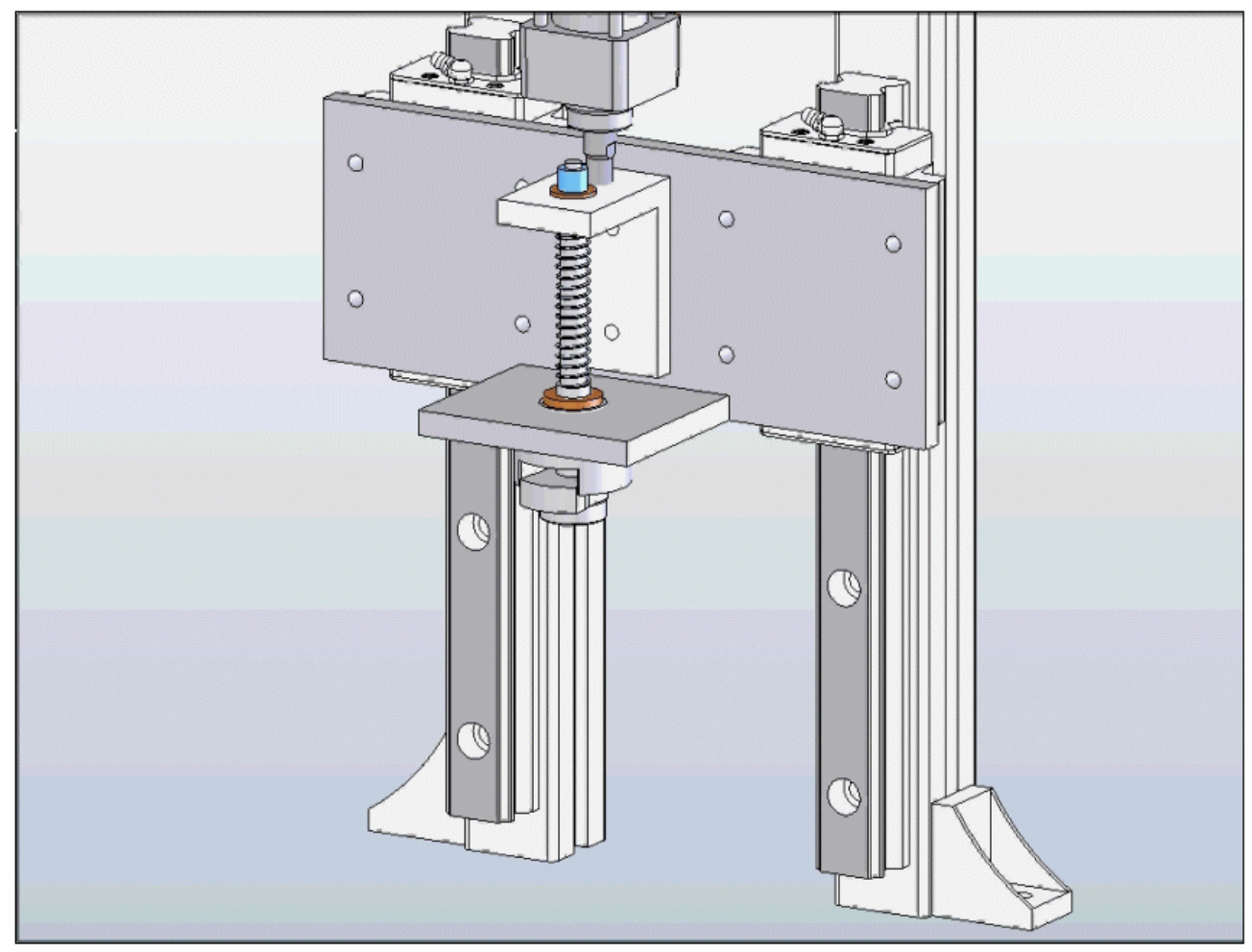

Figure 4: Prototype of loading mechanism for Continental Conveyor project 


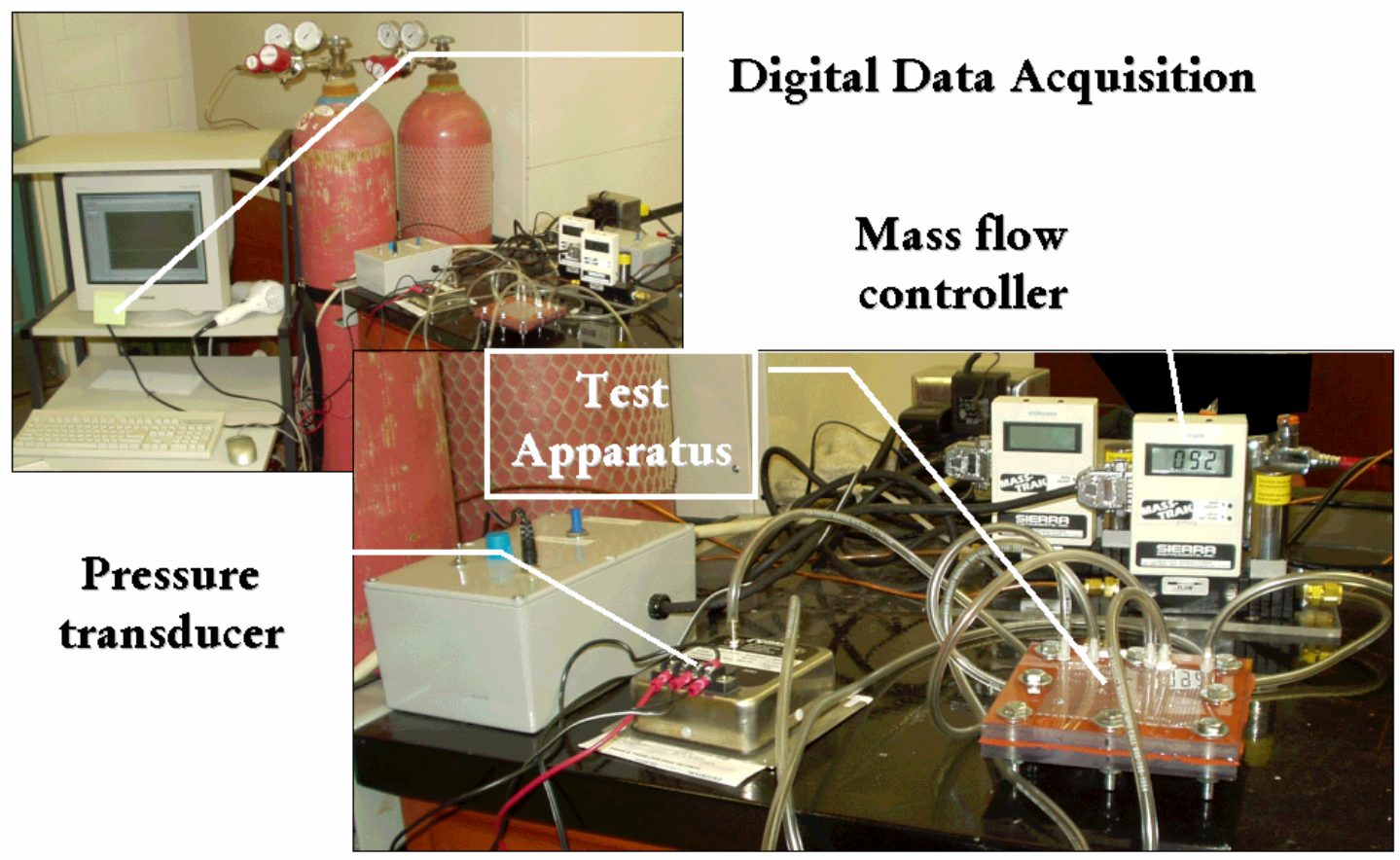

Figure 5: Test apparatus for Hydrogenics fuel cell project

Figure 3 illustrates another MECH 460/462 project where the subject was the design of a automated cartridge assembly machine for Continental Conveyor (Belleville). The company specializes in the manufacture of conveyor products. Each belt conveyor consists of a flexible belt running on multiple rollers. Each roller houses two bearings, which are protected by a seal cartridge which in turn prevents particles from entering the roller. A cartridge consists of four parts: a metal retainer, a rubber lip seal, an inner labyrinth, and an outer labyrinth. Each cartridge must be lubricated before final assembly. Currently, the cartridges are assembled manually. The company requested that students investigate the feasibility of automating the assembly process.

Figure 3 shows the machine design that was developed by the students in MECH 460 for the Continental Conveyor project. In MECH 462, two prototypes were constructed. Figure 4 illustrates the physical prototype that was constructed for the loading mechanism. An animated SolidWorks virtual prototype was constructed of the entire machine to verify operations.

The third example project to be presented illustrates that not all MECH 460/462 design projects are not product or "widget" design oriented. The industry sponsor was Hydrogenics (Toronto). The project objective was to design and commission a new testing apparatus that could be used to evaluate components of a Proton Exchange Membrane (PEM) fuel cell. The transport processes in the Porous Transport Layer (PTL) in this type of fuel cell are not well understood. Figure 5 illustrates the test apparatus that was designed and constructed for this project. The design for this permeability testing apparatus was based on a CFD analysis conducted by the students. It was found that the apparatus could successfully characterize the PTL properties with respect to fluid flow and it also illustrated the unique mechanical properties of the PTL.

Table 4 lists the internal design team sponsored projects. In some cases the entire Queen's team will form the MECH 460 or MECH 462 project team. In other cases, when the Queen's team is quite large, the MECH 460 or MECH 462 project team will be a subset of this group working on a specific sub-system design. These projects do not receive any MMO funding.

Independent of the nature of project's sponsorship, each group is required to produce a poster to summarize their project at the conclusion of $\mathrm{MECH}$ 460. An example is given as Figure 6. This poster is presented as part of a "project fair" that is organized at the end of term. The industry clients act as judges in this event. 


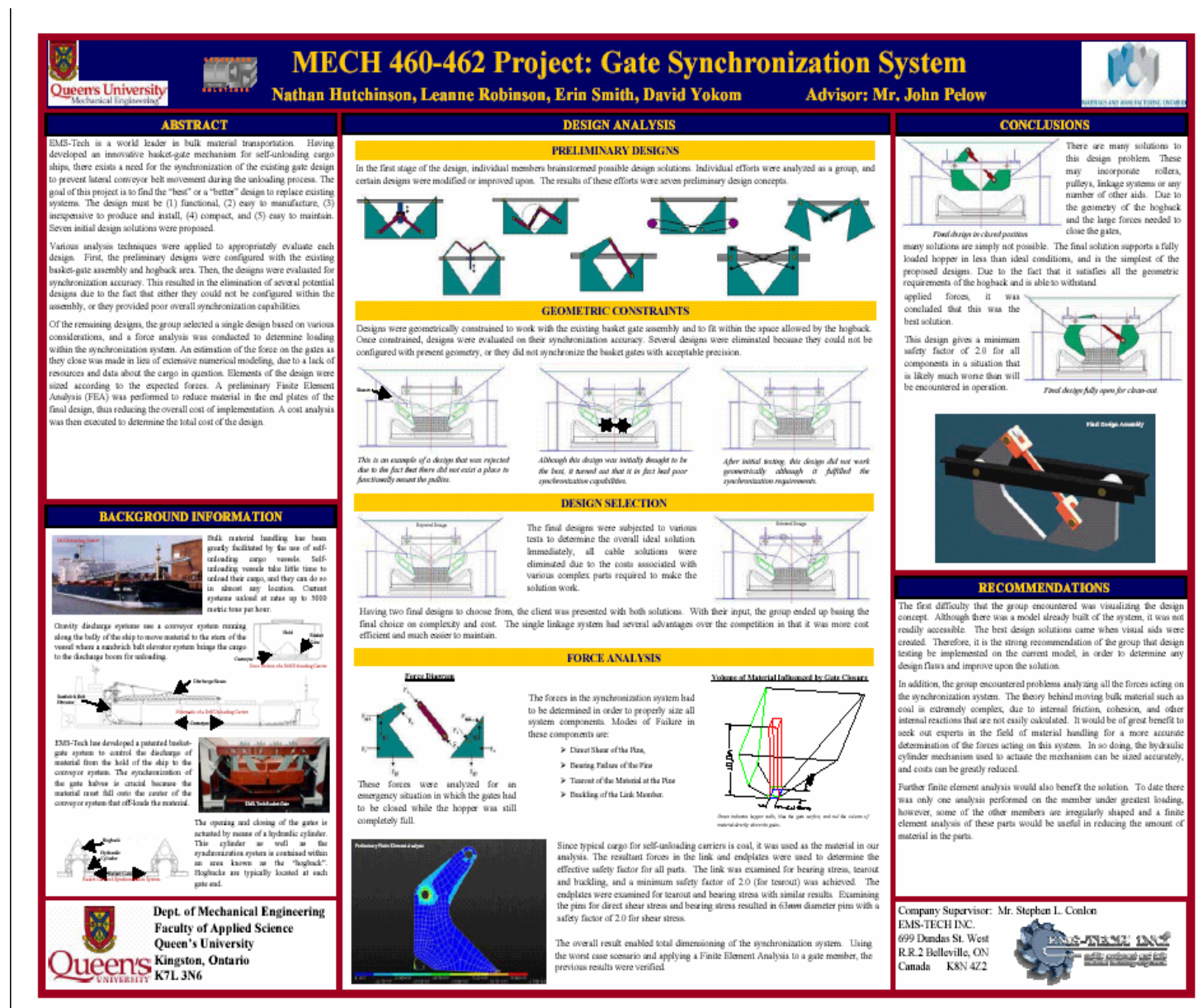

Figure 6: Sample MECH 460 poster

Table 4: Competition Teams and Projects in Fall 2004

\begin{tabular}{|l|l|}
\hline \multicolumn{1}{|c|}{ Team } & \multicolumn{1}{c|}{ Project } \\
\hline Queen's Aerodesign & Pod Aerodynamics \\
\hline Queen's Mini Baja & Drive Train Design \\
\hline Queen's Formula \#1 & Chassis Design \\
\hline Queen's Formula \#2 & Suspension Design \\
\hline
\end{tabular}

\section{Guidelines for Industry Based Projects}

There is no simple template for successful industry sponsored final year engineering design projects. There are too many uncontrollable (or at least poorly controlled) variables. Not the least of which is the interaction of a group of individuals. However, experience has shown that there are several key characteristics that are common in projects that otherwise appear quite different which can lead to a successful or unsuccessful project.
"Good" and "Bad" Project Characteristics Some general characteristics that can be used to define "good" and "bad" projects are listed and described below.

Problem definition: The scope of the project must be appropriate for the level of experience of the students involved and there must be a clear design component. Projects that expect too much of the students or projects that are investigative rather than design oriented should be vetted by the course coordinator or modified by the industry advisor proposing the project. The exact project scope in each case may be difficult to define at the beginning of the project given the broad range of companies involved. However, experience has shown that the project scope should include a clear list of expected outcomes and that this is a useful guide when determining the level of experience required of the team. Often the project scope is used more as a guide than a prescriptive outline and can be modified as the 
project progresses. The more detail included in the problem definition, the higher the likelihood of success for the project, regardless of how much the project scope changes during the actual project.

Team dynamics: The way in which the team of students works together will play a large role in the success of the project. This aspect of the project cannot be predetermined completely, but given the chance to choose their own team does allow students the opportunity to work with a group of peers who are well aware of each others personalities. Expected levels of cooperation, enthusiasm, commitment and the relevant skill sets are most often known within the group from the outset. Counseling from the academic supervisor or course coordinator in this regard can also be helpful (see below). Assuring that the team members have clearly defined tasks and responsibilities throughout the term of the project also helps maintain a good team dynamic. Particular roles and responsibilities for each team member may change during the project in order to give participants experience with different tasks.

Industry advisor support/guidance: Support and guidance from the industry advisor is critical throughout the project. Regular communication (see below) between the industry advisor and the student group is essential. An alternative industry contact should be available if the project requires input from others within the organization and in case the primary contact person is unavailable due to travel or illness. A high level of commitment to the project must be acknowledged by the industry advisor. A clear understanding of the course objectives (a useful learning experience, not a consulting job) by the industry advisor is also needed.

Academic supervisor monitoring: The academic supervisors involved in the projects must take an active roll in guiding the students through the process. It is not necessary for the academics to contribute to the design work. In fact, it should be discouraged other than offering constructive criticism and directing students to where they can find more information. The role of the academic supervisor should be to keep the project moving forward by reminding the students of the scope, objectives and timetable. Students typically work to weekly deadlines. Without regular reminders of the tasks that need to be accomplished over the course of a term, a team can quickly find themselves behind schedule and not able to successfully finish all the original objectives.
Communication between all involved: This aspect of the project cannot be overstated. Only through regular interaction between everyone involved will projects come to a successful conclusion. Time and again projects with a well defined scope, good team and well meaning supervisors will not reach a successful conclusion because there was poor communication between the parties involved. The different people involved may start out with different expectations regarding the project objectives, the timetable or the overall scope. Only through regular communication of all aspects of the project and the decisions that are made during the term will a project stand any chance of success.

Finally, it should be noted that good projects can go bad for any number of reasons and projects that look rather bad from the outset can end up being good. However, the underlying course objective is to provide the students with a useful learning experience in regard to conducting themselves in a team effort to achieve a design goal. Regardless of the final outcome, be it a complete working prototype or an incomplete set of engineering drawings with no clear relationship to the original project, if the students have learned something about the process (what makes it work, what makes it not work) the project is a success.

\section{Some Helpful Hints}

Some hints that may assist others who are contemplating starting this kind of course or who are currently offering a similar course are stated briefly here. Start early looking for industry sponsors for each year's new crop of projects. Do not hesitate to recycle projects that worked well in previous years (with a slight modification of the problem definition or objectives possibly being necessary). Regular communication between the students, the academic advisor and the company supervisor is essential. A strong "buy-in" from all people involved is required. Multi-stage and multi-faceted projects are a good way to train students in the art of multi-tasking and may help in avoiding an all-or-nothing conclusion at the end of the project. Provide the time and the mechanism for rapid and effective communication between the industry supervisor and the academic advisor during the evaluation of the projects. Provide a mechanism for providing useful feedback to the students. 


\section{Conclusions}

There is no easily defined formula for success when running a final year capstone team-based, industrysponsored design course. Experience has shown that a clear problem definition, good team dynamics, strong industry advisor support, regular academic supervisor input and ongoing communication between all parties involved should result in a successful project. Failure of the project or group of people involved to meet any or all of these performance objectives does not necessarily mean a project will be a failure. When considering the broad course objectives (a positive learning experience) the most important part of the course is the feedback that the students get based on their performance during the project. The assessment mechanisms built into MECH 460 and MECH 462 are meant to provide this feedback to students and hopefully provide everyone with as positive an experience as possible.

\section{Acknowledgements}

Student members of the Pennsafe project were Amanda Knuston, Greg Malicki, Stacey Smith and Patrick Waller. Their academic supervisors were Dave Strong and Doug Boyd. Their industry contact was Tim Accursi. Student members of the Continental Conveyor project were Eric Dionne, Susan Hayes, Jonathan Killing and Iris Monner. Their academic supervisor was John Pelow. Their industry contact was David Lynn. Student members of the Hydrogenics project were Matt Shewan, Alex Wilhelm, Eric Nadeau and Matt Skarel. Their academic supervisor was Jon Pharoah. Their industry contact was Rob DelCore.

\section{References}

[1] Wild, P.M., Surgenor, B.W., Mulvenna, C.A., and Bradley, C. "The Challenges of Final Year Engineering Design Projects", $11^{\text {th }}$ Canadian Conference on Engineering Education, Halifax, July 1998, pp.5-7.

[2] Mechefske, C.K., "Industry Sponsored Final Year Engineering Design Projects: A Template for Success", ASEE Annual Conference, Alburquerque, New Mexico, June 24-27, 2001, Session 1566.

[3] Miller, D.W, Brodeur, D.R., and Keesee, J.E., "The CDIO Capstone Course: An Innovation in Undergraduate Systems Engineering Education", ASEE Annual Conference Proceedings, Montreal, Quebec, June 16-19, 2002, Session 1302.

[4] Malmqvist, J., Young, P.W., Hallstrom, S., Kuttenkeuler, J. and Svensson, T., "Lessons Learned from Design-Build-Test Based Project Courses", International Design Conference, Dubrovnik, May 18-21, 2004.

[5] Kline, A.A., and Aller, B .M., "Involving Industry in Capstone Design Courses: Enhancing Projects, Addressing ABET Issues, and Supporting Undergraduate Engineering Practice", ASEE Annual Conference Proceedings, Montreal, Quebec, June 1619, 2002, Session 1302.

[6] Giolma, J.P. and Nickels, K.M., "Herding Cats: A Case Study of a Capstone Design Course", ASEE Annual Conference Proceedings, Montreal, Quebec, June 16-19, 2002, Session 1302. 